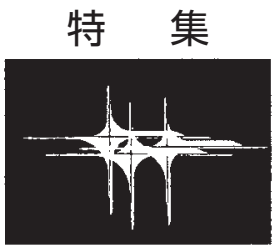

\title{
特集：医療機器・介護機器開発を正しくおこなうための 関連法とガイドラインの理解
}

\section{臨床試験の実施について一試験実施医師の立場から}

小出 邦博*, 須藤一彦*1, 桃野 友太*2, 木村 芳孝**3

\section{1. はじめに}

国産医療機器の承認件数の件数は, ここ数十 年あまり多くないという話をよく聞く，実際， 我々の今回の承認は, 産科領域で治験を実施し, 医療機器として承認を受けた初めての機器であ る。これに対し，海外勢の国内での承認申請は ロボットを使った医療機器, 手術のパワーデバ イス開発，血管ステントなどコンスタントにお こなわれている印象を受ける。国産の医療機器 の承認件数が少ない要因は様々あると思うが, その一つに, 医療機器の臨床研究のルールや手 順の整備が十分ではなかったことがあげられ る. 我々は, これらルールおよび手順作成の黎 明期から現在の臨床研究法施行までの間に, 治 験を実施し製品化を経験することができたので 問題点と解決法を踏まえて我々の医療機器開発 と承認に関し報告したい。

\section{2. 治験と特定臨床研究}

さて近年は, 臨床研究法が施行されて, 臨床 試験の手続きがますます複雑で時間がかかるよ うになってきた，数枚の申請用紙で臨床研究 を実施していた時代からみると，比べ物にな らない枚数と資料の種類が増えた。ただ，臨 床研究の手続きはここ 10 年間で徐々に改善し ていき, 臨床研究法の施行で一定の区切りを つけられた感がある。

* 東北大学大学院医学系研究科融合医工学分野

*1 アトムメディカル(株)モニタリングシステム部

$* 2$ 東北大学病院 産婦人科

*3 みやぎ県南中核病院 産婦人科
臨床研究法として法律で規制しなければ，国 民の信頼を得られない時代になってしまったこ とは嘆かわしいことであるが，手続きとしては 本来あるべき姿に近づいているのだろうという 実感がある．今後は品質の高い臨床研究がおこ なわれることを期待する一方，申請から承認さ れるまで数ヶ月かかることについては，大いに 改善が必要なことは多くの研究者が穾感してい るとことだと思う。

さて, 臨床研究法の施行により臨床研究は図 1 のように「治験」「特定臨床研究」「それ以外 の臨床研究」に分類された。

臨床研究法において「臨床研究」とは, 医薬 品等を人に対して用いることにより，当該医薬 品等の有効性または安全性を明らかにする研究 と定義されている.

また, 特定臨床研究とは, 以下に該当する臨 床研究である.

(1)未承認・適応外の医薬品等の臨床研究

(2)製薬企業等から資金提供を受けた医薬品 等の臨床研究

我々が経験した治験は臨床研究の一部であ
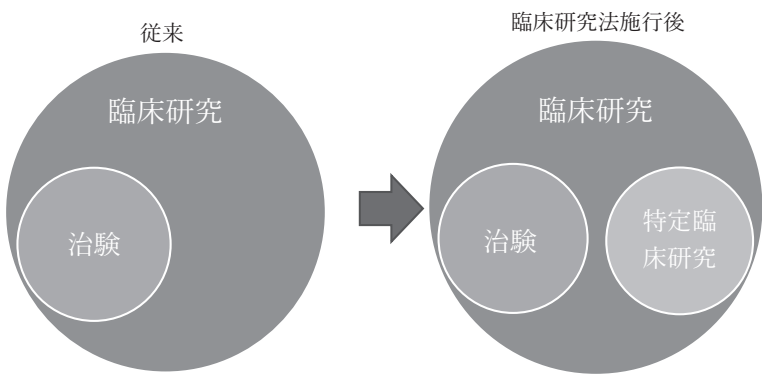

図 1 臨床研究とは 
表 1 臨床研究の分類と従うべき法律

\begin{tabular}{|l|c|l|}
\hline \multicolumn{1}{|c|}{ 臨床研究の分類 } & 従うべき法律 & \multicolumn{1}{|c|}{ 基準遵守義務 } \\
\hline 特定臨床研究 & \multirow{2}{*}{ 臨床研究法 } & あり \\
\cline { 1 - 1 } 特定・治験以外の研究 & 努力義務 \\
\hline 治験 & 医薬品医療機器等法 & あり (GCP 省令 $)$ \\
\hline
\end{tabular}

表2 臨床研究法と医薬品医療機器等法の目的

\begin{tabular}{|c|c|}
\hline 法律 & 目的 \\
\hline 臨床研究法 & $\begin{array}{l}\text { 臨床研究の対象者をはじめとする国民の臨床研究に対する信頼の確保を図ること } \\
\text { を通じてその実施を推進し，もって保健衛生の向上に寄与すること. }\end{array}$ \\
\hline $\begin{array}{l}\text { 医薬品医療 } \\
\text { 機器等法 }\end{array}$ & 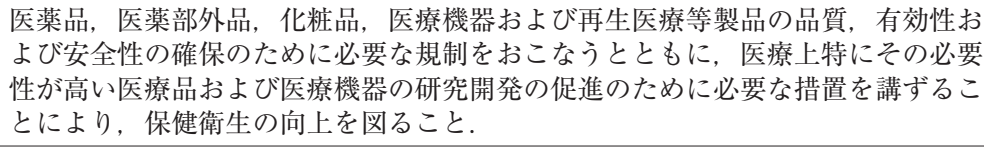 \\
\hline
\end{tabular}

るが，従うべき法律と目的が異なる.

それぞれの法律が目指すところは表 1 , 表 2 の通りである.

厚生労働省の「臨床研究法について」のホー ムページには，これからおこなう研究が特定臨 床研究に該当するのか否かを判定するための チェックシートや, 揃えるべき必要書類の例が ある．強引な言い方をするが，従うべき法律と 目的（治験は，承認申請が目的）が異なるだけ で, 治験と特定臨床研究では, 我々研究者が対 応する内容とそれにかかる時間は，それほど変 わらないのではないかと思っている。研究計画 書, 同意説明文書, 各種手順書, 利益相反管理 書類, 医薬品等概要書など十数種類の書類の作 成とその管理, さらに, 治験と特定臨床研究で はモニタリングと監査が必須であり, 臨床研究 で得られたデータの科学的な質とデータの信頼 性を担保することが必要不可欠となる。いずれ にしろ，これらすべてを正しく実施するには， 外部の専門家 (CRO) に委託するのが一般的 だが，相当の費用が掛かるので，あらかじめ予 算計画を綿密に立てておかなければならない. 企業主導か医師主導かによってかかる費用の財 布は異なるが，国ではさまざまな助成をおこ なっている. 例えば, 特定臨床研究の審査を受 けるだけで数十万円の費用が発生するが，その 費用を助成する仕組みが用意されている。 これ らをうまく利用することも研究成功のカギの一
つとなる.

\section{3. 我々が経験した製品化までの道のり}

我々は，産科領域で胎児の心拍数を高精度に 測定でき，かつ，従来は不可能とされていた胎 児の心臓の電気信号を連続記録できる装置の製 品化に成功した。図 2 に製品化までの道のりを 記す。雑音に埋もれた中から微小信号を抽出す る新しい原理を考案し, 特許化, 基礎研究, 臨 床研究, 治験, そして製品化へと約 10 年間の 長い道のりであった，途中，東日本大震災に見 舞われるなど，壊滅的な困難にも遭遇したが， 多くの人の力添えのおかげで, 無事 2018 年 7 月に製品化することができた.

治験実施を決意してから PMDA の承認をい ただくまでに約 5 年かかった。この期間が長い のか平均的なものかは我々にはわからないが, 期間短縮のための反省点は多々存在する。一番 の反省点は，デー夕の記録方法に明確な基準を 設けなかったために, 担当者によって解釈が異 なり，そのデータのクリーニングに多くの手間 と時間を要したことである.

具体的には，測定中の様子をワークシートに 記録することをプロトコルで決め, 測定中に被 験者が咳払いしたとか，手を動かしたなどの状 態を“文字で”原データとして記録した。微小 な信号を測定することが目的なので，このデー タから体動などのアーチファクトの影響を分析 


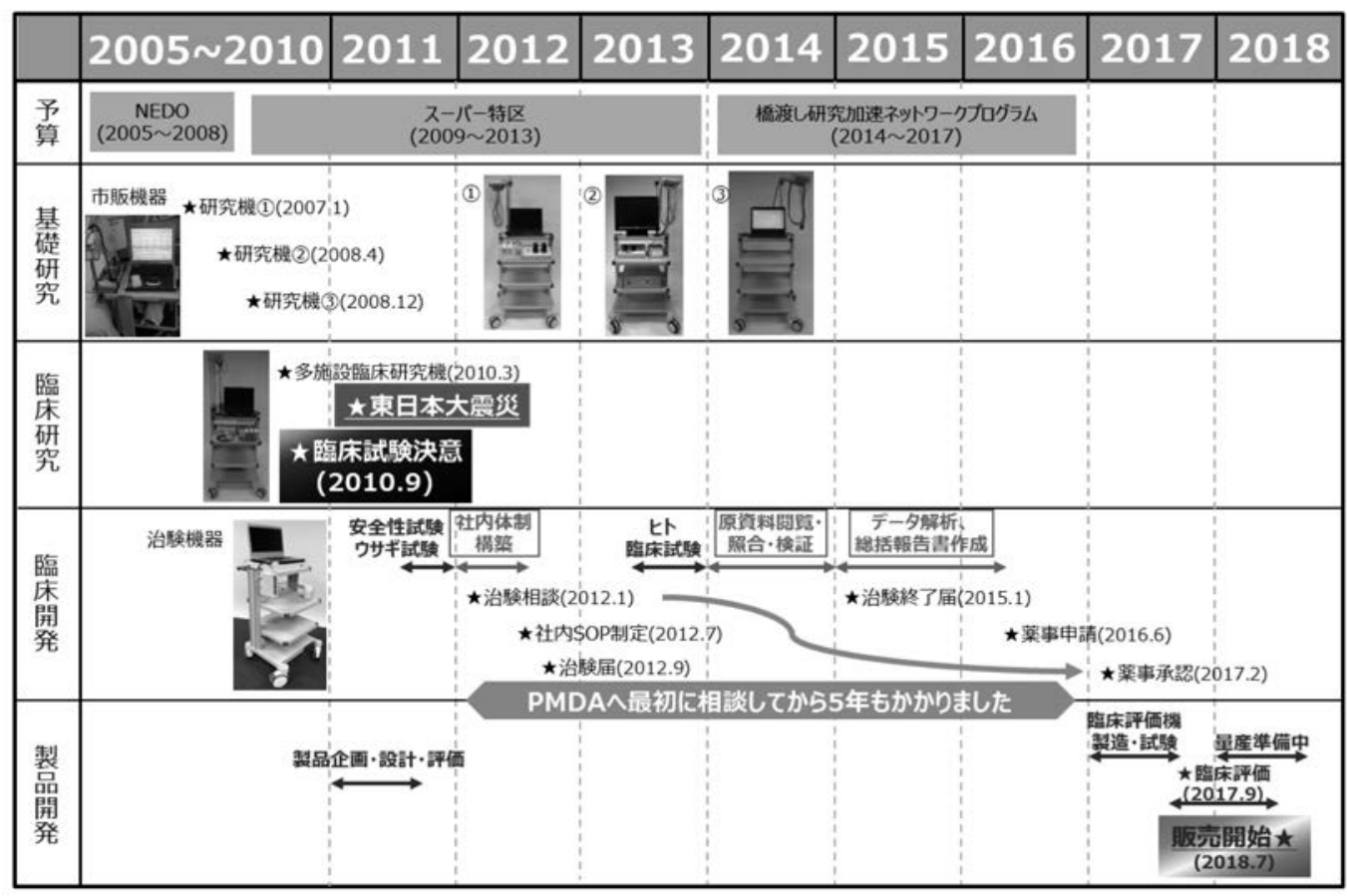

図2 製品化までの道のり

するためにプロトコルに記載したが，記録の表 現方法を統一できていなかったことから, 記録 者の主観が入り，モニタリングで記録の不備を 指摘され，その対応に多くの時間を費やした。 本当に必要なことだけを誰でも同じようにデー 夕収集できる計画となるように心がけたい.

さて, 臨床研究に関するルールの変化につい ては, 2014 年 11 月 25 日に薬事法の大改正が おこなわれ, 医薬品医療機器等法が施行された. 71 年間も使われてきた法律名に, 初めて,「医 療機器」の文字が記載されるという大きな変化 を遂げた時期でもあった，改称のポイントは, 以下の 3 点で, これは, 医学や電子機器および 先端医療の進歩に連動した時代の要請といえる.

(1)医療機器の承認・許可に係る規定を, 医薬 品の規定から独立させる

(2)再生医療等製品を新たに規制対象に加える (3)安全性等に係る規定の強化, 明確化を図る 法改正に連動して, 臨床研究の進め方, 書類 の書き方なども手探りの中から着実に前進して いき, この黎明期の時代に医療機器の臨床研究 を経験したことは, 我々および大学の支援部門
にとって, 非常に有意義であったし, 特に治験 を実施した企業が蓄積したノウハウはとても大 きなものであったと考えている. 一方, 臨床研 究法は薬事法の改称から 3 年後の 2017 年 4 月 1 日に施行された。 その目的が, 国民の臨床研 究に対する信頼を回復させるためというのも, 嘆かわしいことではあるが, ある意味, “時代 の要請”なのかもしれない.

\section{4. 研究の成果}

図 3 は, 治験で得られた成果をもとにアトム メディカル(株より製品化された心拍数モニ夕 「アイリスモニタ®」である.お母さんのおなか の上にシート状の電極を貼ることで, 非侵襲的 におなかの中の赤ちゃんの心拍数を測定, 表示, 保存することができる.

超音波ドプラ法による従来機器より詳細に 胎児の心拍数を測ることができ, さらに, 従来 は不可能とされていた胎児の心臓の電気信号 (胎児生体電気信号) を非侵襲的に連続記録す ることができる。

治験のプロトコルは以下の通りで, 被験機器 

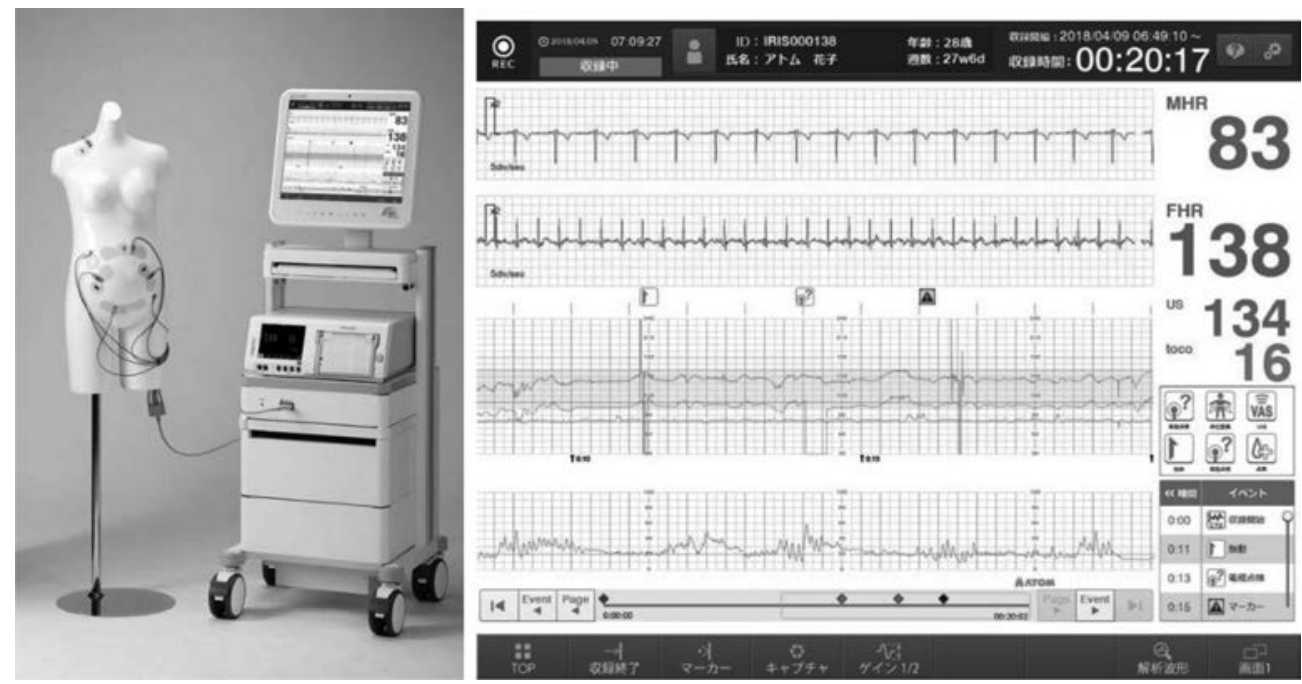

図3

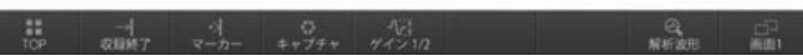

アイリスモニタ ® とその表示画面
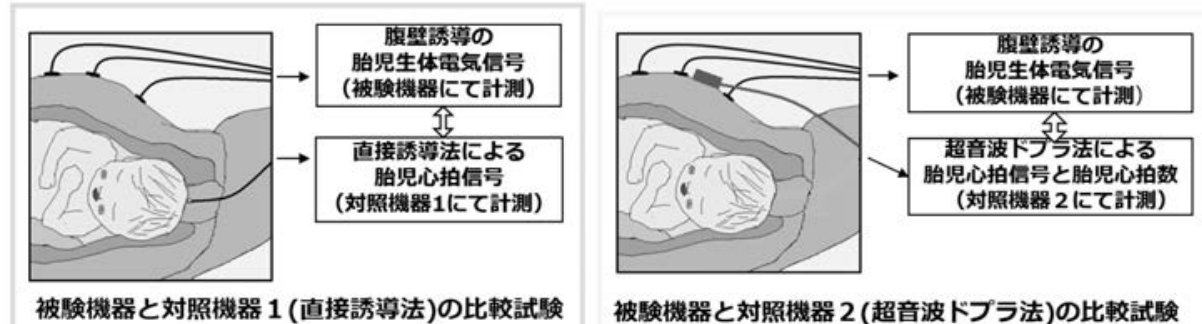

被験機器と対照機器 1 (直接誘導法)の比較試験

被験機器と対照機器 2 (超音波ドプラ法)の比較試験

\begin{tabular}{|c|c|c|c|c|}
\hline & \multicolumn{2}{|c|}{ グループ 1} & グループ 2 & グループ 3 \\
\hline 妊娠週数 & \multicolumn{2}{|c|}{ 37～42週末満 } & 32 37週末満 & 24～32週末満 \\
\hline 登録数 & \multicolumn{2}{|c|}{ 7例 } & 6例 & 10例 \\
\hline 計測項目 & 胎児心拍信号 & $\begin{array}{l}\cdot \text { 胎児心拍数 } \\
\cdot \text { 胎児心拍信号 }\end{array}$ & $\begin{array}{l}\cdot \text { 胎児心拍数 } \\
\cdot \text {-胎児心拍信号 }\end{array}$ & $\begin{array}{l}\text { ·胎児心拍数 } \\
\text { · 胎児心拍信号 }\end{array}$ \\
\hline 計測機器 & $\begin{array}{l}\text { 被験機器 } \\
\text { 対照機器 } 1\end{array}$ & $\begin{array}{l}\text { 被験機器 } \\
\text { 対照機器 } 2\end{array}$ & $\begin{array}{l}\text { 被験機器 } \\
\text { 対照機器 } 2\end{array}$ & $\begin{array}{l}\text { 被験機器 } \\
\text { 対照機器 } 2\end{array}$ \\
\hline
\end{tabular}

図4 治験プロトコル

と対照機器 2 種類の比較試験をおこなった（図 $4)$.

対照機器 1 (直接誘導法) と比較した結果, 約 97\%で同一心拍としてとらえた（図 5 ).

対照機器 2 (超音波ドプラ法) と比較した結 果，約 85\%で同一心拍をとらえた（図 6 ).

以上の結果より, 同等性が認められ, 改良 医用機器（臨床試験あり）としてPMDAより 承認を得た。

\section{5. 結語}

臨床研究は, 医学に携わる研究者の日常の仕 事である，そのルールと手続きを研究者が理解 していることは必要ではあるが, 必ずしも一人 で抱え込む必要はない. 所属機関の支援部門な どの協力を得ながら上手に進めてもらいたい. また，法律や規制は時代に応じて変化するもの である，目まぐるしい変化に時にルールを守る 

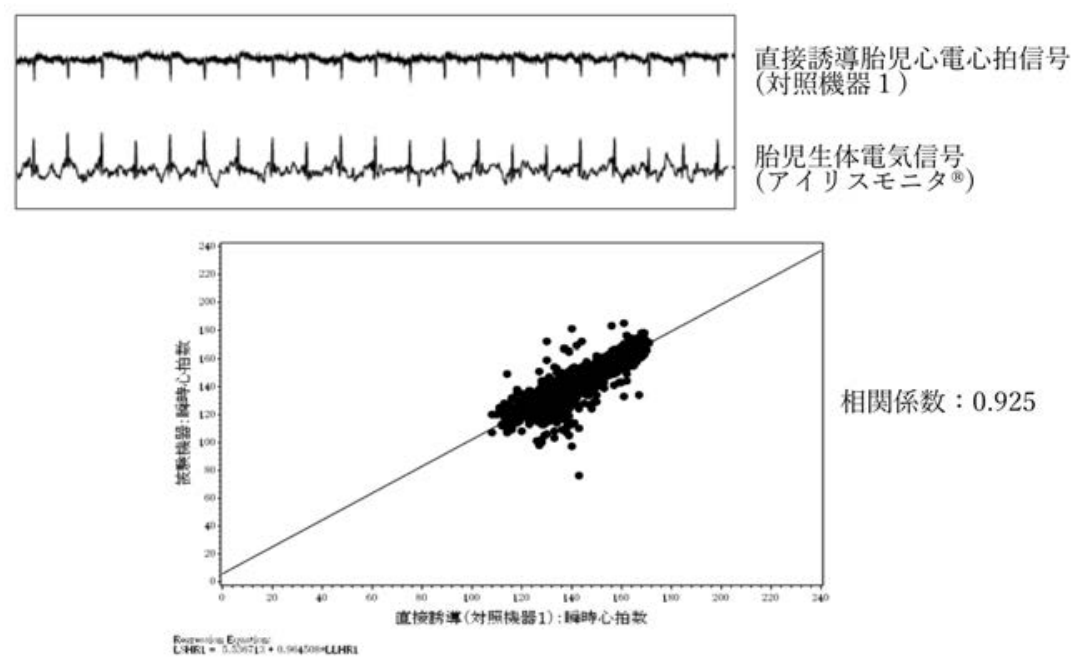

図5 結果 1

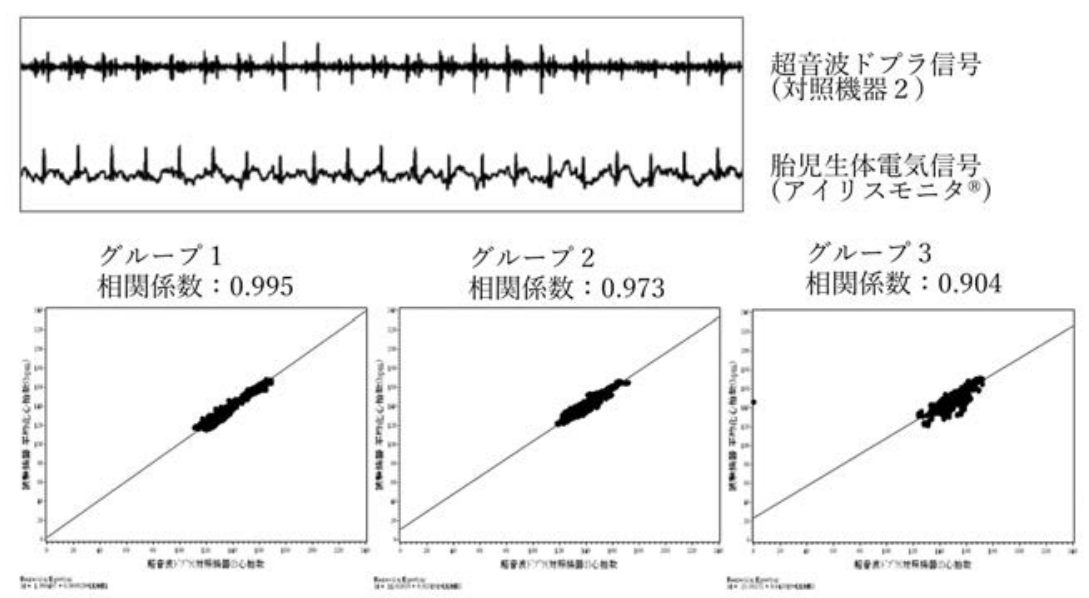

図6 結果2

ことが目的と勘違いしがちになるときもある が, 我々の本業は真理の追究であることを忘れ てはならない.

我々が治験を通じて実感したことは，自らが 発見したシーズが必ず社会に役に立つのだとい う信念と様々な障壁に負けない熱い情熱があれ ば, 結局何とかなるものだということ, そして, 良きパートナーに恵まれたことも忘れてはなら ない。 今回, 企業治験を実施して製品化まで実 現してくれたアトムメディカル(株), 様々な相談 に乗ってくださった東北大学の支援部門, 治験 について助言をいただいたPMDA，そして研
究予算の支援をしてくださった国の関連省庁に 媣く感謝している.「産」「学」「官」のまれ? な成功例の一つとして良い経験をしたと思って いるが, 我々の経験がこれから医療機器の開発・ 製品化を目指している研究者たちへの後押しに なれば幸いである。

最後に, 医療機器の臨床研究に関していえ ば，十数年前と比べて手続きは格段に複雑に なったが，製品化への道のりはきれいに舗装さ れ案内標識が整備された。今後, 国内での革新 的技術を使った医療機器の製品化がますます活 発になることを祈念して結語とする。 